\title{
Transnational Corruption and the Globalized Individual
}

\author{
Abstract \\ This paper presents a new, more transnational, networked perspective on corruption. It is \\ premised on the importance of professional intermediaries who constitute the infrastructure of \\ cross-border illicit finance, the blurring of legal and illegal capital flows, and the globalization of \\ the individual via multiple claims of residence and citizenship. This perspective contrasts with \\ notions of corruption as epitomized by direct, unmediated transfers between bribe-givers and \\ bribe-takers, disproportionately a problem of the developing world, and as bounded within \\ national units. We argue the professionals in major financial centers serve to lower the \\ transaction costs of transnational corruption by senior foreign officials. Wealthy, politically \\ powerful individuals on the margins of the law are increasingly globalized as they secure \\ financial access, physical residence, and citizenship rights in major OECD countries. These \\ trends are evidenced by an analysis of the main components of the relevant transnational \\ networks: banks, shell companies, foreign real estate, and investor citizenship programs, based \\ on extensive interviews with key informants in a dozen countries.
}




\section{Introduction}

This paper presents a new, more transnational and relational view of corruption emphasizing the roles of intermediary professionals and increasingly globalized individuals. Rather than conceiving of corruption as a feature of discrete sovereign states, particularly among developing countries, we argue that corruption is increasingly instantiated in transnational networks of intermediaries that link actors, institutions, and processes across developing and developed states. Thus we question the conventional dichotomy of "clean" rich states and corruption-prone poor states, and the corresponding practice of ranking states; blur any strict separation between licit and illicit political economies; and re-orient the level of analysis in studying corruption away from states toward global networks and the individuals comprising the nodes within them. Corruption impoverishes poor countries not just by inhibiting economic development at home, but also by redirecting existing capital away from productive domestic uses and toward consumption abroad. In policy terms, countering these kinds of transnational illicit flows should be an important pillar of a comprehensive anti-corruption strategy, and one where international institutions and wealthy countries can have the most leverage.

The particular empirical focus of the article is on grand corruption or kleptocracy, i.e., corruption by senior public officials and their associates. Globalized kleptocrats exploit four transnational channels in particular to launder their stolen wealth: banks, shell companies, foreign real estate, and second citizenship and investor visa programs. Highlighted by the revelations contained in the "Panama Papers," 11.5 million pages of documents leaked in April 2016 from law firm Mossack Fonseca, these connected transnational sites collectively serve to 
turn initially ill-gotten gains into ostensibly legitimate assets and legal rights. They do so by disembedding these funds from their origins, and affording their owners important protections, such as the rights to privacy and security of property.

In presenting our argument, we first substantiate the claim that the dominant tendency in studying corruption has tended to adopt a "methodologically nationalist" approach that focuses on the state as the unit of analysis. Country-by-country corruption ratings and rankings are often used to proxy the dependent or independent variable in observational quantitative studies aiming to discern the effects or causes of corruption. More recent experimental scholarship on corruption has generated important new knowledge, but like earlier qualitative and anthropological work, because they tend to be focused on a single country or locality these studies once again divert attention from transnational links and networks. In turn, analyzing corruption in terms of isolated country-units has informed an incomplete and distorted policy picture of relatively clean developed states and corruption-prone developing states, while tending to ignore how facilitators based in the former set of countries stimulate and enable crime in the latter.

The second section provides some background on the primary empirical focus of the paper: grand corruption or kleptocracy, synonyms referring to large-scale corruption carried out by senior political officials. In practice, kleptocracy almost always involves a cross-border aspect, as funds stolen by leaders of one country are transferred via intermediaries and hidden in abroad. We draw upon earlier work inspired by a transaction costs approach that stresses the role of intermediaries in corrupt practices and the resulting illicit financial flows, rather than simple, unmediated models of a bribe-giver and recipient. 
When it comes to grand corruption, professionals like bankers, lawyers, realtors, and corporate service providers are crucial in constituting illicit financial networks (even if their individual actions may be deemed legal), and facilitating the flow of capital from poorer to rich countries. Drawing on extensive interviews with informants in over a dozen countries, we present and analyze the professionally-mediated sites that constitute the transnational networks allowing for the transfer of wealth and the wealthy from poor to rich states: cross-border banking facilities, shell companies, international real estate, and second citizenship and investment visas. In each case, specialized professionals, especially lawyers, are crucial. A transaction cost analysis drawing on the new concept of "Global Wealth Chains" sheds light on how these networks ease the flow of funds, undermine accountability, and promote exit. Though tens of billions of dollars of foreign money has recently flowed into properties in a few "world cities," and more than half the member countries of the OECD's member states now effectively sell citizenship or residency, these developments have been relatively neglected by academics and policymakers. The rules or guidelines meant to guard against professionals, such as real estate brokers and lawyers, facilitating such illicit transfers tend to be weak and rarely enforced by OECD regulators.

The significance of this discussion hinges on three main points. First, by demonstrating how large-scale corruption among elites in poor countries is crucially enabled by networks of professional intermediaries based in rich countries, our evidence complicates and brings into question the conventional notion that corruption is predominantly a problem of the developing world. Second, the fact that most cross-border transfers of the proceeds of corruption are mediated not by criminal middle-men but by established and often highly-reputed firms of 
professionals in the legal, banking, consultancy and real estate sectors illustrates the merging of the licit and illicit economies. Third and finally, we see an increasing globalization of the individual in these developments. The fraying of ties between increasingly mobile, cosmopolitan multinational corporations and states was seen to epitomize globalization in the 1990s, with states competing to attract and retain footloose capital. Now, wealthy individuals are globalizing through acquiring multiple nationalities via investor citizenship programs, and diversifying their sites of physical, legal, and tax residence, once again with the assistance of a specialized industry of professional intermediaries. Just as states have striven to retain fiscal and regulatory control over "their" corporations while competing to attract new investment from outside firms, a similar dynamic has now arisen with regards to wealthy global individuals.

\section{Bringing Transnational Networks Back into Corruption Research}

Corruption came onto the international agenda from the early 1990s in the wake of the end of the Cold War. ${ }^{1}$ At the national level, corruption had long been criminalized (in the United States as far back as the constitution), and thus neither corruption nor domestic legal and policy responses are new. What was new in the 1990s was seeing corruption as an international governance problem, rather than just a domestic matter amenable to local criminal investigative and regulatory solutions. Multilateral lending institutions like the World Bank, donor governments, regional international clubs like the Organization of American States, and a burgeoning range of transnational NGOs, all supported a strong new anticorruption norm and

${ }^{1}$ Eigen 1996; Rose-Ackerman 1999; Wang and Rosenau 2001; Rothstein 2011; Vogl 2012; Gutterman 2014. 
agreed that corruption required a collective response. The policy conventional wisdom changed from seeing corruption as something that might be tolerated or even encouraged to facilitate international transactions, to now being viewed as a major barrier to economic development. ${ }^{2}$

\section{Corruption and Methodological Nationalism}

Writing over a decade ago, Michael Johnston insightfully characterized the literature on corruption as being disproportionately divided into one cluster of statistical work, aiming to assess the causes and consequences of corruption using country-by-country metrics, and another built on detailed single case studies of particular national contexts. ${ }^{3}$ He lamented the lack of dialogue between these two strands of scholarship. More recently, a new school of experimental work has augmented earlier scholarship. Of course given the wealth of research on corruption, there are many other approaches, from more deductive hypothetical exercises, to normative theorizing. ${ }^{4}$ Despite their differences, the dominant large- $N$ scholarship, the single case study, and the experimental approaches generally share a methodological nationalism: corruption is conceived and measured in discrete, bordered national units.

Political scientists and economists in particular have disproportionately concentrated on the large- $N$ statistical approaches. ${ }^{5}$ This generally requires a national measure of corruption levels, or at least perceived corruption levels. The usual aim here is to find what effect varying levels of (perceived) corruption have on some dependent variable of interest, most often economic growth, but also a whole range of other outcomes, from democracy to infant mortality.

2 Klitgaard 1988; Shleifer and Vishny 2002; Bukovansky 2006 and 2015; Weaver 2008.

3 Johnston 2005.

${ }^{4}$ See Matthew Stephenson's 244-page bibliography on the subject, www.law.harvard.edu/faculty/mstephenson/Stephenson Corruption Bibliography.pdf

${ }^{5}$ For reviews, see Treisman 2007; Lambsdorff 2007; Rose-Ackerman 2010; Wedel 2012. 
The corollary is to use these national corruption measures as the dependent variable with an eye to determining what causes corruption (religious or colonial heritage, region, resource endowments, etc.), and how it can be best countered (e.g., a free press, development aid, a dedicated national anti-corruption agency, etc.). Recurrent correlations in the cross-national work have entrenched a picture of relatively corrupt developing countries and relatively clean developed countries.

Experiments carried out in the laboratory, by survey, and particularly in naturalistic settings in the field provide a path toward stronger causal inferences about corruption. In expectation, random assignment of populations to control and treatment groups neutralizes the effects of all observed and unobserved confounds, leaving a clear and unbiased picture of cause and effect. Ingenious experimental studies have shed important new light on corruption in areas as diverse as road-building in Indonesia to driving license tests in India. ${ }^{6}$ Yet it is striking the extent to which much of this experimental work is comprised of single case studies of coutnries from Mali to Mexico. ${ }^{7}$ Critics of experimental approaches in development economics have specifically focused on the difficulty generalizing from the very local context of the experiment, commonly one locality or a few villages, to the world at large. ${ }^{8}$ Though there is no reason in principle why experimental work cannot be transnational, ${ }^{9}$ in practice the localism of most of this work once again tends to direct attention away from the increasing importance of cross-border networks in enabling large-scale corruption.

This methodological nationalism has been further reinforced by the emergence, in both scholarship and policy-making circles, of international corruption and governance rankings.

${ }^{6}$ Olken 2007; Bertrand et al. 2007.

${ }^{7}$ Gottlieb 2016; Chong 2015.

8 Rodrik 2008.

${ }^{9}$ Findley et al. 2014. 
These include the Corruption Perceptions Index (CPI), compiled by the Berlin-based NGO Transparency International, the World Bank's Worldwide Governance Indicators, and indices designed by various for-profit concerns (e.g., the Economist Intelligence Unit). ${ }^{10}$ These and other measures have constituted a view of corruption as primarily the act of domestic bribe-taking by public officials. Remedial and review mechanisms similarly take the individual country in isolation as the unit of analysis and intervention. Thus Transparency International conducts detailed qualitative assessments according to its National Integrity System framework. ${ }^{11}$ Compliance with the various inter-governmental corruption agreements is once again assessed on a state-by-state basis, with the OECD Anti-Bribery Convention country monitoring reports being the early and influential example. ${ }^{12}$

These scholarly and applied studies have greatly advanced our understanding of corruption and produced many insights. But as noted earlier, this work has also tended to obscure the increasingly transnational nature of corruption) the tendency of illicit funds to flow from poor to rich countries, and the need to follow the money through networks to major financial centers. Most media accounts of acts of bribery that have been uncovered in developing countries will usually mention the nationality of an investing company, describe the investment vehicles or legal schemes that facilitated the deal, and even speculate as to where the funds have ended up. Yet, our scholarly and policy lenses de-emphasize these same transnational elements. Below we provide a different, more transnational and relational perspective on corruption that links richer and poorer countries together within illicit networks and financial flows.

${ }^{10}$ For a discussion of these indicators, see Cooley and Snyder 2015, Merry et al. 2015; Andersson and Heywood 2009.

$11 \mathrm{http}: / /$ www.transparency.org/whatwedo/nis/ http://www.oecd.org/daf/anti-bribery/countryreportsontheimplementationoftheoecdanti-briberyconvention.htm 


\section{A Transnational Perspective on Corruption and Kleptocracy}

In this paper we look at a priority that has received increased attention over the last decade: rich countries hosting the proceeds of corruption taken from poor countries. Though petty corruption can have immediate and severe consequences for those in developing countries, whether it is denial of health care or exposure to policy brutality, kleptocracy tends to impoverish whole societies, and subverts any notion of accountable or representative government. ${ }^{13}$ This kind of large-scale corruption is almost always intermediated, rather than being simply an exchange between two parties. Critically, the intermediaries most commonly involved are legitimate businesses and actors providing for-fee services (bankers, lawyers, realtors), rather than criminal middlemen. The three central implications of this perspective are, first, to bring into question the conventional dichotomy of rich clean countries and dirty poor ones; second to blur any strict separation between illicit and licit economies; and third, to globalize the individuals engaged in grand corruption, effectively disembedding them from their home states.

Some important early policy responses to corruption were explicitly transnational. Perhaps the most significant of these was the OECD's anti-bribery convention. ${ }^{14}$ While bribing local officials had long been prohibited, bribing foreign officials was legal almost everywhere bar the United States up until the late 1990s. Yet even here practice remains national. As noted, signatory countries to the convention are reviewed for compliance on an individual basis, and there is little or no effort by these states to co-ordinate with the states whose officials are bribed

13 StAR 2007.

14 Abbott and Snidal 2002; Gutterman 2014. 
by OECD-based corporations. ${ }^{15}$

Though the transnational problem of Western multinational corporations bribing foreign government officials certainly remains important, this paper is primarily concerned with major corruption perpetrated by state leaders, senior officials, and their families. Such kleptocracy almost always has an international aspect, as the criminal proceeds are moved abroad, or in some cases, never enter the kleptocrat's home country at all. ${ }^{16}$ Such cross-border transfers complicate the detection, investigation, and return of looted assets. ${ }^{17}$ Furthermore, because the destination or host countries for this money are conventionally states with large financial centers like the US, UK, and Switzerland, such transfers provide access to a wide range of professional intermediaries, as well as tempting options for conspicuous consumption.

Though the tendency of money stolen by the leaders of poor countries to end up in the banks and luxury real estate holdings of rich countries had long been noted anecdotally, this pattern has only really begun to stimulate a co-ordinated international policy response over the last decade or so. ${ }^{18}$ In the aftermath of scandals involving the stolen assets of kleptocrats like Ferdinand Marcos of the Philippines and Sani Abacha of Nigeria, the 2005 UN Convention Against Corruption was crucially premised on a norm of stolen assets being returned from "host" to "victim" countries. ${ }^{19}$ Even more relevant has been the combined United Nations/World Bank Stolen Assets Recovery (StAR) initiative. The 2007 StAR founding document explained the rationale for the initiative with the argument that responses to corruption had concentrated too much on developing countries, and not enough on the foreign financial centers that host the

15 StAR 2014a.

16 StAR 2011; Chayes 2015.

${ }^{17}$ Shelley 2014.

18 StAR 2007, 2009.

19 Pieth 2008; Borlini and Nessi 2014. 
resulting dirty money. The significance of this neglect is that "corruption will remain a profitable crime in developing countries as long as counterparts in rich countries are willing to hide stolen resources." 20 Yet the idea of corruption as predominantly a developing country problem retains a strong hold on both scholars and policy-makers, distorting our understanding of the nature, consequences, and remedies for this phenomenon.

\section{How Transnational Networks of Corruption Operate}

Whether it is foreign direct investment or aid, capital movements between rich and poor countries are in the main seen as flowing from the former to the latter. More recent literature on illicit financial flows, however, concentrates on a reverse movement of money from poor to rich countries, comprised of the proceeds of capital flight, tax evasion, and corruption. ${ }^{21}$ Here we first lay out the conceptual logic of the role played by the intermediary professionals that facilitate the movement of white, gray, and black funds from poor to rich countries, drawing on work informed by transaction cost economics. We then present evidence to substantiate the three main contentions presented in the Introduction. To this end, coverage is focused on the most important components of these networks: cross-border banking, shell companies, foreign real estate ownership, and second citizenship and investor visa programs. In each case, rather than just an individual customer in a developing country and seller in the developed, these transactions are mediated by professional intermediaries who variously operate within, on the margins of, or beyond the law. Much of the evidence below is taken from extensive interviews with these same intermediaries, as well as regulators, law enforcement personnel, and NGOs.

20 Fontana 2011: 1.

21 Baker 2005; Reuter 2012. 
Why are Professional Intermediaries Important? A Transaction Costs Approach

Although the role of global intermediaries has been under-emphasized in the study of corruption, it is important to acknowledge the exceptions who have blazed the trail. For example, Lambsdorff foregrounds intermediaries as part of his transaction costs approach. ${ }^{22} \mathrm{He}$ draws on Oliver Williamson's dichotomy of markets, where firms contract with each other in the production process, and hierarchies, where firms internalize such processes. ${ }^{23}$ Lambsdorff's analogy is that firms can directly offer bribes themselves (the "in-house" approach or "make"), or contract an agent to do the dirty work (e.g., lawyers or consultants, the "buy" option). Which strategy they will adopt depends on the nature of the transaction (e.g., one-off or recurring), and the nature of the counterpart. Firms interested in giving a bribe must trade off the specialized skills and plausible deniability provided by intermediaries against increased costs and risks of opportunism.

Like Lambsdorff's treatment of intermediaries, the idea of illicit Global Wealth Chains builds on the same foundation of transaction cost economics. ${ }^{24}$ It takes more direct inspiration from the idea of Global Value Chains, used to explain the governance and co-ordination of geographically dispersed production processes among different actors. ${ }^{25}$ This notion expands the markets/hierarchies dichotomy by including three intermediate categories (modular, relational, captive) between pure market and pure hierarchy. The different forms are determined in large part by the varying extent of the scope for opportunism, asset specificity, and co-ordination costs. Rather than the production process, for Seabrooke and Wigan the referent is the

\footnotetext{
22 Lambsdorff 2013.

23 Williamson 1975, 1985.

24 Seabrooke and Wigan 2014.

25 Gereffi, Humphrey and Sturgeon 2005.
} 
management of wealth, and rather than efficiency, the primary purpose of wealth chains is avoiding accountability. Inferring from the prevalence of multiple specialized intermediaries in the laundering of transnational corruption funds, the transaction costs of illicit networks seem to be quite low compared to laundering the proceeds of drug trafficking, where laundering is mainly a do-it-yourself affair for traffickers. ${ }^{26}$

We argue that these brokers and intermediaries play three main functions in the transnational corruption network. First, and in line with Lambsdorff's framework, kleptocrats have contracted out the management of their stolen wealth (opting to "buy" rather than "make" in house). In doing so, they benefit from the specialized skills of professional intermediaries. The fact that these intermediaries are themselves legal rather than criminal businesses reduces the danger of opportunism. Second, these intermediaries serve to shield individuals engaged in corruption networks from accountability, as per the Global Wealth Chains thesis. Whether bankers, accountants, residency consultants, or realtors, brokers serve to obscure identities, create legal proxies for clients, obfuscate roles and provide new spaces for corrupt officials to keep their wealth and to physically reside. There is an important, almost paradoxical dynamic here: as the parallel norms of individual accountability in human rights and grand corruption have been greatly strengthened, ${ }^{27}$ an entire range of global industries has emerged to buffer individuals from being held accountable for their corruption.

Finally, these global services and practices constitute the final link in the transnational corruption network: that of "exit" in the formulation of Albert Hirschman. ${ }^{28}$ Breaking with the methodological nationalism of corruption rankings not only necessitates looking at the

${ }^{26}$ Levi and Reuter 2006; for a parallel application with regard to people smuggling, see Sanchez 2014.

${ }^{27} \mathrm{Kim}$ and Sharman 2014.

${ }^{28}$ Hirschman 1970. 
transnational networks of bribe-givers, facilitating vehicles and brokers, but also the process, sequences and methods through which corrupt officials manage to evade national regulators and law enforcement, launder moneys and maintain legal protections if their criminal activities are detected by their home country authorities. A revealing example comes from a secret People's Bank of China report written in 2008 and accidently leaked in 2011. The report describes how in the period 1993-2008 between 16,000 and 18,000 Chinese officials fled the country with $\$ 123$ billion in state assets. ${ }^{29}$ The leading destination countries for the senior cadres were the United States, Canada, and Australia, countries that lack extradition treaties with the PRC. ${ }^{30}$ In April 2015, China's Central Commission for Discipline Inspection publicly released a list of one hundred most wanted economic fugitives accused of economic crimes including money laundering, bribery and embezzlement, of whom 66 were believed to be residing in the United States and Canada. 31

Besides the general "pull" factors that attract foreign funds such as a concentration of financial markets and secure property rights, what else attracts gray or black money from abroad seeking refuge? Below we discuss a range of factors, some reasonably obvious, such as international banking facilities, others less so, including the availability of intermediaries like lawyers and realtors, as well as investor visas and second citizenship schemes. Rather than being separate concerns or professionals sectors, these elements are closely linked in practice.

29 People's Bank of China, “A Study on Methods of Transferring Assets outside China by Chinese Corruptors and Methods of Monitoring this Problem," Beijing, 2008.

30 Though controversially Canada began negotiations with China about such a treaty in September 2016, "Ottawa to Negotiate Extradition Treaty with China," Global and Mail online, September 20, 2016.

31 "China releases 'most wanted' list of economic fugitives," CNN Money http://money.cnn.com/2015/04/23/news/china-most-wanted-economic-fugitives/index.html 


\section{The Mechanisms of Transnational Corruption}

The broad range of corruption crimes (passive and active bribery, extortion, embezzlement, nepotism, trading in influence) has often been simplified to the exemplary instance of a bribe-giver and recipient. ${ }^{32}$ In practice, however, major corruption offences typically involve a range of intermediaries. Banks are perhaps the best known of these, and thus the treatment of their role is correspondingly brief. Less attention has been devoted to shell companies, but especially to the importance of real estate and second citizenship and investor visa programs for the globalized individual, simultaneously coordinating cross-border investments and residencies with different bespoke nationalities. In accord with the thesis about the blurring of licit and illicit economies, it is crucial to stress that these channels host a spectrum of legal and illegal funds. We certainly do not maintain that, for example, all or even most of the foreign money flowing into North American and Western European real estate represents the proceeds of crime.

\section{$\underline{\text { Banks }}$}

All banks are legally bound to refuse money that they know to be of criminal origin, to monitor their clients, and to report suspicious transactions to law enforcement. ${ }^{33}$ Nevertheless, there is a strong suspicion that only a tiny minority of the dirty money passing through banks is effectively identified as such. ${ }^{34}$ Based on mostly on Swiss financial transaction data, Zucman estimates that there is a total of at least $\$ 7.6$ trillion in global hidden wealth, with banks in Switzerland and Luxembourg channeling and recycling most of these unaccounted funds. A

32 Johnston 2005; Wedel 2012.

33 Reuter and Truman 2004; Jakobi 2013.

34 Global Witness 2009; StAR 2009; US Senate 2010; Financial Services Authority 2011; UNODC 2011. 
database compiled in 2011 by the Stolen Assets Recovery initiative showed that of 213 cases of grand corruption involving a combined total of $\$ 56.4$ billion, the most common locations for the associated bank accounts were the United States (107), Switzerland (76) and the UK (19). There is good reason to think that huge sums of criminal money continue to flow into financial centers like New York, London, Zurich, Singapore, and Dubai. ${ }^{35}$ Rather than just a resting place for funds, however, banks also construct and mediate transnational networks. According to Zucman, having attracted capital, banks often further direct their foreign clients' wealth into mutual funds, typically based in Luxembourg. ${ }^{36}$ The massive data dump from the Panamanian law firm Mossack Fonseca in April 2016 epitomized the scope and scale of the relevant networks, but also more specifically revealed that among the more than 500 banks contracting its services, those based in Switzerland, the UK, and Luxembourg were the firm's most important customers. ${ }^{37}$ Interviews with a wide range of both bankers and regulators indicate that there has been a pronounced goal displacement when it comes to the extensive, expensive, and intrusive system of regulations designed to keep criminal monies out of transnational banking networks. Thanks to the increasing frequency and severity of penalties levied against banks, especially as applied to the United States government, the aim of banks' compliance departments is not so much to catch or screen out criminals, as to satisfy regulators. Compliance becomes a formalistic exercise where bank staff, relying heavily on compliance software, vet transactions by the country of origin of the transaction, rather than beneficial owner and the underlying activity that generated the funds. As a result, even high-risk clients can evade detection with the assistance of skilled

35 OECD 2013; StAR 2014b; Johanessen and Zucman 2014.

36 Zucman 2015.

37 https://panamapapers.icij.org/graphs/ 
global professionals mediating the relationship with the bank. ${ }^{38}$

\section{$\underline{\text { Shell Companies }}$}

Those in law enforcement and regulatory agencies are almost unanimous that shell companies that obscure the identity of the real owner are the main stumbling block to combating cross-border financial crime. ${ }^{39}$ The same 2011 Stolen Asset Recovery initiative report on kleptocracy referenced above found that of the 213 cases of cross-border corruption, no fewer than 150 involved the use of corporate entities. ${ }^{40}$ In 112 cases these were shell companies that lacked a substantive business purpose, but were instead used to conceal the identity of the real person or people in control of assets legally owned by the company. Rather than end-users setting up shell companies directly, they are created and marketed through chains of wholesale and retail corporate service providers, ${ }^{41}$ Mossack Fonseca being one of the world's biggest. ${ }^{42}$ Of the 91 instances where the database contained sufficient information, 72 involved a professional intermediary to set up the company, creating another link in the chain between the corrupt official and the money. ${ }^{43}$

38 Author interviews, U.S. Treasury Department, Washington D.C., February 12, 2015; Swiss Financial Intelligence Unit, Geneva, Switzerland, October 13, 2015; international auditing firm, New York City, May 4, 2015; National Crime Authority, London, UK, December 14, 2015; Cayman international bank, Washington D.C., December 9, 2014; U.S. Department of Justice, Washington D.C., December 9, 2014; international bank, New York City, November 21, 2014; international bank, Nassau, the Bahamas, May 13, 2014; international bank, Hong Kong, October 18, 2011.

39 OECD, Paris, France, April 19, 2016; Swiss Financial Intelligence Unit, Geneva, Switzerland, October 13, 2015; World Bank, Washington D.C., February 12, 2015; former FBI agent, Washington D.C., February 9, 2015; National Crime Authority, London, UK, December 14, 2015; U.S. Department of Justice, Washington D.C., December 9, 2014.

${ }^{40}$ StAR 2011: 34.

${ }^{41}$ StAR 2011; Findley, Nielson, and Sharman 2014.

42 Author interview, Mossack Fonseca, Panama City, April 2, 2008.

${ }^{43}$ StAR 2011: 117-122. 
A 2014 OECD report on international bribery tells the same story concerning the importance of shell companies in international corruption. It analyzes 427 cases from the period 1999-2014, finding that in 71 percent of cases bribes were paid through an intermediary or shell company. ${ }^{44}$ In a majority of cases the illegal payments were routed through OECD states' financial systems. These data on the prime importance of major financial centers in hosting tainted wealth are further supported by an extensive field experiment undertaken by Findley, Nielson, and Sharman who found, based on over 7400 solicitations to company providers around the world, that OECD providers of shell companies were significantly more likely than those in either developing countries or tax havens to offer to sell a shell companies without obtaining proper identifying documentation from the buyer. ${ }^{45}$

The evidence above shows that the importance of shell companies for cross-border illicit flows was established well before the Panama Papers. But the information leaked forcefully supports the central points of this paper concerning the transnational nature of corrupt flows, the prominence of intermediaries, the blurring of legal and illegal business, the globalization of the individual, and the financial ties that bind poor, rich, and tax haven conduit countries. Material from the Panama Papers shows the tendency of funds to flow through networks from poorer to richer countries. The largest markets for Mossack Fonseca's shell companies were China, Russia, and Latin America, with the most popular product being those formed in the British Virgin Islands, rather than Panama as such, though companies from more than a dozen other jurisdictions were available (including Nevada, New Zealand, and the UK). ${ }^{46}$ Extensive

44 OECD 2014: 28-29.

45 Findley, Nielson, and Sharman 2014.

$46 \mathrm{https}: / /$ panamapapers.icij.org/graphs/, http://www.theguardian.com/news/2016/apr/03/what-you-need-to-know-about-the-panama-paper s. 
interviews indicate that this geographical distribution is fairly typical of the shell company market more generally. ${ }^{47}$ Importantly, however, Mossack Fonseca is a wholesale operation rather than a retailer of shell companies. Instead of selling direct to end-users, the firm sold to a network of more than 14,000 intermediary firms, typically banks, law, and accounting firms. These intermediaries are disproportionately based in Hong Kong, Switzerland, Jersey, London, and Luxembourg. ${ }^{48}$ The networked nature of even the simplest typical arrangement involving Mossack Fonseca underlines our central theses. Thus a Chinese individual might use a Hong Kong accounting firm to source a British Virgin Islands company from the Panamanian wholesaler with which to hold a Swiss bank account through which to invest in Luxembourg mutual fund. The number of links in this indicative Global Wealth Chain suggest relatively low transaction costs.

\section{$\underline{\text { Foreign Real Estate }}$}

Though the data are (as always) incomplete, a narrower focus on property supports the conclusion that cities such as New York, Miami, London, and Paris are major destinations for a combination of licit and illicit wealth from the developing world. The transfer of this wealth is once again facilitated by networks of professional intermediaries, specifically real estate brokers and lawyers. These agents are either are not required to identify the real owners of these purchases, or regularly fail to do so in practice.

${ }^{47}$ Author interview shell company providers, London, UK, April 27, 2016 and December 3, 2015; Geneva, Switzerland, June 16, 2015 and June 20, 2013; New York City, October 30, 2014; Nassua, the Bahamas, May 13, 2014; Barcelona, Spain, September 25, 2013; Vaduz, Liechtenstein, June 26, 2013; Charlestown, Nevis, April 17, 2013; Port Louis, Mauritius, February 15, 2013; Victoria, the Seychelles, February 11, 2013; Avarua, Cook Islands, December 4, 2009; Singapore, October 20, 2009; Apia, Samoa, June 29, 2009; Willemstad, Netherlands Antilles, February 23, 2009.

48 Obermayer and Obermaier 2016. 
According to the inaugural luxury real estate survey released by Christie's in 2013, six North American cities (New York, Miami, San Francisco, Toronto, Los Angeles, and Dallas) placed in the top ten of global luxury real estate markets (defined in terms of total annual listings over \$1 million), with London, the Cote D’Azur, and Paris ranking first, second, and fifth respectively. The only non-Western city was Hong Kong, ranking third, while Miami, London, and the Cote D'Azur topped the list of most international buyers as an overall percentage of sales. The 2014 annual report of the US National Realtors Association comments on how the types of homes purchased by international buyers of US property typically differ from domestic ones, observing that international buyers acquire US property less in order to meet their “essential living needs," and more for establishing an "individual's presence and standing in the community." ${ }^{49}$ The same report found that during the period April 2013-March 2014 international purchasers accounted for about $\$ 92$ billion, or 7 percent of the total market, with international purchasers exceeding both the mean and the median purchase prices of domestic buyers. ${ }^{50}$

Interviews with government officials, industry analyses, and reports by investigative journalists all confirm that luxury real estate worldwide is increasingly being bought via shell companies using specialized real estate and law firms. ${ }^{51}$ In each of these instances, a typical transaction might involve a foreign bank (often not in the official's home country) making a wire transfer to the trust account of a law firm and/or real estate agent in the host country, who then buys the property in the name of a local or foreign shell company. Hence a corrupt foreign

49 NAR 2014: 12.

50 NAR 2014: 5.

51 Author interviews, Treasury Department, Washington D.C., February 12, 2014; Department of Justice, Washington D.C., December 9, 2014; National Crime Agency, London, UK, December 14, 2015; Transparency International UK 2015a. 
official is distanced both from the source of the funds used to buy the property, and the ownership of the property itself. ${ }^{52}$

Remarkably, the disclosure and due diligence rules for real estate brokers operation in these top luxury markets (United States, Canada, France, and Hong Kong) are significantly more lax than in the banking sector, though they vary across country (See Table 1). In the United States lawyers and realtors have neither a duty to establish the legitimacy of clients' funds, nor to report suspicious transactions to the authorities. After the passage of the Patriot Act in 2001, the US National Association of Realtors secured an exemption from a requirement that would have mandated that brokers conduct due diligence on purchasers. ${ }^{53}$ Without the requirement of having to ascertain beneficial owners, real estate transactions via shell companies can effectively bypass bank reporting requirements.

One striking investigation into the buyers of condos at the TimeWarner Center, one of Manhattan's most exclusive properties, revealed the extent of these anonymizing trends. The report found that while in 2003 about one-third of all purchases in the luxury building were acquired by shell companies, by 2014 the figure had increased to 80 percent. Overall since 2005

52 Author interview, private lawyer, London, UK, December 9, 2015; International Centre for Asset Recovery, Basel, Switzerland, October 14, 2015; Transparency International UK, London, UK, December 10, 2015; Global Witness, New York City, September 24, 2014, Open Society Foundations, New York City, February 13, 2015; private lawyer, Washington D.C., February 10, 2015.

53 Author interview, Treasury Department, Washington D.C., February 12, 2015. In 2012, the NAR released this statement: "NAR supports continued efforts to combat money laundering and the financing of terrorism through the regulation of entities using a risk-based analysis. Any risk-based assessment would likely find very little risk of money laundering involving real estate agents or brokers. Regulations that would require real estate agents and brokers to adopt anti-money laundering programs may prove to be burdensome and unnecessary given the existing ML/TF regulations that already apply to United States financial institutions." http://investmentwatchblog.com/hsbc-money-laundering-drug-trafficking-and-terrorist-financing /\#RkEemW1VhoZmbaAZ.99 
across the United States, the number of purchases of residence worth more than $\$ 5$ million has tripled, while half of all of these luxury sales in 2014 were made to shell companies. Between April 2014 and March 2015, overseas buyers bought more than $\$ 100$ billion worth of real estate in the United States. ${ }^{54}$ Fifty-five percent of these transactions were all cash. ${ }^{55}$ In terms of purchasing countries of US real estate in 2014, buyers from China, Taiwan, and Hong Kong accounted for $\$ 28.6$ billion of sales, by far the leading foreign buyers. According to a survey of Chinese investment in US real estate commissioned by the Asia Society, the average home price for Chinese buyers rose from $\$ 590,800$ in 2014 to $\$ 831,800$ in 2015 ; half of these buyers were nonresidents of the United States and 39 percent of them expressed their intention of using these homes as primary residences. ${ }^{56}$ Between 2013 and 2015, on average, 71 percent of all residential purchases by Chinese buyers were on an all cash basis. ${ }^{57}$

An undercover sting operation by NGO Global Witness graphically revealed the typical mechanisms by which corrupt foreigners can move tainted funds to buy New York real estate. ${ }^{58}$ A confederate impersonated an advisor to the minister of mines from an unnamed West African country. He met with 13 New York lawyers looking for advice on how to purchase a \$10 million house in New York City, with the funds described as "black money" and "facilitation payments." One lawyer explained the common practice of using the law firm's own trust account to receive foreign funds for US property acquisitions. All except one of the lawyers recommended using a shell company and/or trust to own the property. ${ }^{59}$

54 "Wealthy Foreigners bought $\$ 100$ billion in Real Estate, $C N B C$ June 22, 2015.

55 "Wealthy Foreigners Bought $\$ 100$ billion in Real Estate," CNBC June 22, 2015

56 Rosen et al 2016: 41-42.

57 Rosen et al 2016: 41.

58 Global Witness 2016.

59 Global Witness 2016, p.7. 
By 2016, the issue had become so pressing that the US Treasury's Financial Crimes and Enforcement Network (FinCEN) rolled out a series of trial new regulations of "geographical targeting orders" designed to ascertain the identity of all foreign buyers paying "all cash" for luxury real estate units by mandating that transactions conducted through shell companies reveal the buyer's beneficial owner to title insurance companies. Tellingly, the pilot program initially targeted foreign purchases in the Manhattan (over \$3 million purchases) and the Miami (over \$1 million purchases) markets. The program was then extended to encompass six US markets in New York, California and Texas. ${ }^{60}$ FinCEN officials revealed that over $25 \%$ transactions covered in the initial pilot involved a beneficial owner who was also the subject of a FinCEN "suspicious activity report." 61

The London market is even more penetrated by foreign and anonymous buyers. According to one report by Transparency International UK based on police data, at least $£ 122$ billion of property in England and Wales is owned by companies with offshore registration. In London, of the 40,725 properties owned by foreign companies, 89 percent of those were registered in offshore jurisdictions, including the British Virgin Islands, Jersey, Guernsey, Luxembourg, and Panama. British Virgin Islands-registered entities had accounted for about 5,000 buyers from 2012 to $2014 .{ }^{62}$ In the UK lawyers and real estate agents do have the legal duty to scrutinize the seller, but hold no such obligation towards the purchasing entity, regardless 60 "U.S. Title Insurers Required to Identify High-End Cash Buyers in Six Major Metropolitan Areas" July 27, 2016. At: https://www.fincen.gov/news/news-releases/fincen-expands-reach-real-estate-geographic-targeti ng-orders-beyond-manhattan

${ }^{61}$ Sean Stewart-Muniz "Feds Expand Controversial Tracking of Secret Home Buyers to broward, Palm beach and More." The Real Deal July 27, 2016: http://therealdeal.com/miami/2016/07/27/feds-expand-controversial-tracking-of-secret-home-buy ers-to-broward-palm-beach-and-more/

62 Transparency International UK 2015a. 
of whether it is a named individual or company registered offshore with no identified beneficial owner. ${ }^{63}$ Once again, the Panama Papers show how networks comprised of over 2,800 shell companies formed by Mossack Fonseca allowed mainly foreign owners to hold 6,000 British properties. ${ }^{64}$ A secretly filmed sting similar to the Global Witness one referenced above exhibited realtors and other intermediaries recommending that obviously corrupt Russian clients purchase luxury London property via the now-familiar expedients of shell companies, trusts, and local lawyers. ${ }^{65}$

$\underline{\text { Investor Visas and Second Citizenship Programs }}$

Complementing and assisting the spread of wealth across borders is the increasing use of multiple citizenships or residencies, which give rise to the phenomenon of the globalized individual. Corrupt officials looking to exercise their exit options require a haven destination. Once more, intermediaries are important. Governments have long competed for mobile capital by wooing corporate investors, a dynamic often cast as the central leitmotif of the political economy of globalization. ${ }^{66}$ Much less appreciated is the growing competition for mobile capital held by private individuals through investor visa, residency, and second citizenship programs. For those states offering such facilities, the potential rewards are not only an infusion of foreign capital into the local economy, but also a direct revenue gain for the host government. Such programs have been overwhelmingly taken up by individuals from China, the former Soviet

${ }^{63}$ Author interview, private lawyer, London, UK, December 9, 2015; Transparency International UK, London, UK, December 10, 2015; National Crime Agency, London, UK, December 14, 2015..

64 "Revealed: The Tycoons and World Leaders Who Built Secret UK Property Empires." Guardian, April 5, 2016.

65 "From Russia with Cash," July 8, 2015, available at http://www.channel4.com/programmes/from-russia-with-cash.

66 Drezner 2008. 
states, and to a lesser extent elsewhere in the developing world. ${ }^{67}$ Second citizenships offer the globalized individual a level of security of person and property unavailable at home, either because the government is corrupt, repressive and predatory, or because the individual is a fugitive from justice, or often both. In the United States, for example, the EB-5 visa program offers a visa to foreign nationals who invest at least $\$ 500,000$ in projects that create a minimum of 10 jobs; upon the successful completion of the project EB-5, visa holders become eligible for green cards. Since 2010, an estimated 20,000 Chinese nationals have received EB-5 visas. ${ }^{68}$

At the extreme, second (or subsequent) citizenship may involve a relatively simple exchange of money for a passport. One of the pioneers of this route, the Caribbean island federation of St Kitts and Nevis, set up its "economic citizenship" program shortly after independence in 1984 to diversify away from its terminally ailing sugar industry. ${ }^{69}$ Those seeking its passport, and the visa-free travel privileges it provides to the European Union, Canada, and over 100 other countries, must either donate $\$ 250,000$ to a government economic diversification fund, or invest $\$ 400,000$ in approved real estate that must be held for at least five years (most choose the latter; these totals do not include intermediaries' fees). There is no requirement to spend any time actually living in St Kitts and Nevis, though applicants must pass security and character checks.

${ }^{67}$ Author interview, citizenship law firms, Geneva, Switzerland, June 16, 2015; London, UK, December 4, 2015.

${ }^{68}$ Rosen et al. 2016: 9. The report also notes (p. 27) that: "Immigration from China also accelerated in many places through investment visa programs similar to EB-5 . Many high net-worth individuals are now expanding beyond residential purchases, constituting a new wave of commercial real estate investors along with smaller developers and smaller state-owned enterprises."

${ }^{69}$ Author interview, citizenship law firm, Basseterre, St Kitts and Nevis, January 22, 2004 and April 17, 2013; "Passports for a Price: The Business Showing Poor Countries How to Sell Citizenship," Bloomberg, 12 March 2015. 
A common attitude might be that such cash-for-passport deals are the exclusive province of tax havens, but the recent conduct of developed countries belies such sweeping stereotypes. Developed countries are keen to draw a sharp line between others selling citizenship, and their own investor visa programs, but the difference is increasingly one of degree. EU members Cyprus, ${ }^{70}$ Malta, Bulgaria, Portugal, Spain, and others have rolled out new "golden residence permits" and "golden passport programs" in the wake of the financial crisis. ${ }^{71}$ A number of other OECD countries have also introduced new investor visa and residency programs to allow high net worth investors safe residency in exchange for investments in the host country that exceed a certain threshold (see Table 2). For example, in July 2015 Australia augmented its Significant Investor Visa scheme (\$A5 million in approved investments followed by a four-year wait for permanent residency), with a Premium Investor Visa (\$A15 million for permanent residency in a single year). Over 90 percent of the 1311 Significant Investor Visas issued until mid-2015 have been taken up by Chinese nationals. ${ }^{72}$

In the UK, from 2008 the gateway requirement has been $£ 2$ million in approved investments, which entitles the holder to a three-year stay, with a further $£ 5$ million then opening a path to permanent settlement. From 2008 to early 2015, a total of 2377 such visas were granted. ${ }^{73}$ The two leading recipient nationalities, together constituting about 60 percent of the total, were Chinese (1126) and Russians (723), with Pakistan (62), India (60), Kazakhstan (59), and Egypt (58), ranking fourth, fifth, sixth, and seventh. While it is again important to point out

${ }^{70}$ Which offers full citizenship within 90 days, author interview, citizenship law firm, London, UK, December 4, 2015.

71 Shachar and Bauböck, 2014: 3-4.

${ }^{72} \mathrm{https} / / /$ www.border.gov.au/about/reports-publications/research-statistics/statistics/work-inaustralia/significant-investor-visa-statistics

73 Transparency International UK 2015b: 11. 
that much of the money involved may well be legal, the due diligence on the funds involved in such transactions has been very lax. For the UK, the applicant must only demonstrate the source of the funds if they have been in her or his possession for less than three months. ${ }^{74}$ Until 2015 applicants did not have to come up with the money until after they were awarded the visa, and they were not checked for a criminal record. ${ }^{75}$ While the British government has relied on the receiving banks to check the origins of the funds, many banks apparently regard the issuance of the investor visa as confirmation that clients' money is clean, obviating the need for them to conduct separate checks. ${ }^{76}$ Overall, our research indicates that since the financial crisis, about half of all OECD countries have enacted some form of visa, residency, or citizenship for purchase or for investment.

Table 2: New OECD Residency-Investor Programs

ABOUT HERE

Law firms have pioneered this trend. ${ }^{77}$ For example, two of the leaders for economic citizenship programs are the Swiss firm Henley \& Partners, which lists 14 country options in its "global citizenship planning" portfolio, ${ }^{78}$ and Montreal-based Arton Capital, which lists 10 countries in its "empowering global citizenship" site. ${ }^{79}$ Further underlining the artificiality of the supposed division between shady economic citizenship and respectable investor visa programs,

74 https://www.gov.uk/tier-1-investor/documents-you-must-provide

75 Transparency International UK 2015b: 15.

76 Financial Services Authority 2011: 29, 36; Transparency International UK 2015b: 16.

77 Author interview, citizenship law firms, Basseterre, St Kitts, April 17, 2013; Geneva, Switzerland, June 16, 2015; London, UK, December 4, 2015.

$78 \mathrm{https} / / / \mathrm{www} \cdot h e n l e y g l o b a l . c o m /$ citizenship-planning/

79 http://www.artoncapital.com/ 
both firms market British and US citizenship as well as other EU member state and Caribbean options. These firms and others market the programs, pre-screen the clients, and lodge the necessary paperwork with the local government. They also police other unauthorized sellers to preserve their concessions. ${ }^{80}$

A further link is with real estate companies. Countries like St Kitts and Nevis and Cyprus favor investment in real estate, meaning that associated firms build and sell property designed to come in at exactly the minimum cut-off price ( $\$ 400,000$ in the former, $€ 2.5$ million in the latter). Other countries have specifically forbidden such a link, but turn a blind eye when it happens anyway. Australia, for example, disallows direct property investment, but allows Real Estate Investment Trusts, where property is held through a collective investment scheme, to qualify, stimulating yet another cottage industry brokering these arrangements. ${ }^{81}$

\section{Conclusion}

Our analysis suggests that the methodological nationalism which frames much research and policy on corruption skews our understanding of its increasingly transnational nature. Rich and poor countries are intimately intertwined in the Global Wealth Chains that facilitate grand corruption by allowing funds to flow to the former from the latter. "Deviant" kleptocracies and tax havens rely on developed democracies to accommodate bank accounts, corporate entities, and foreign officials' sites of legal and physical residence. These states are host nations where the fruits of these illicit efforts can be enjoyed with the legal protections afforded by Western laws. Speaking of the grand corruption among the elites of a particular developing country is

80 Author interview, citizenship law firm, Basseterre, St Kitts, April 17, 2013.

81 Author interview, realty broker, Brisbane, Australia, July 17, 2015. 
incomplete and misleading in both scholarly and policy terms to the extent that the crucial infrastructure and facilitators that constitute such criminal conduct are irreducibly transnational, rather than bounded or bordered within one state. When it comes to grand corruption, it makes more sense to speak of corrupt networks rather than corrupt countries. Much of this activity appears ordinary and legal precisely because it is structured by international intermediaries acting to reduce transaction costs thanks to their specialized expertise- real estate agents and brokers, law firms specializing in citizenship, bankers and consultants. Illicit networks are thus more intimately tied in to the legal world than is often realized. ${ }^{82}$

What are the specific implications for the way we should research and counter corruption? As much as social scientists may hold the sanguine view that "everybody knows" that corruption is a cross-border problem, the methodologies commonly adopted systematically suggest the opposite conclusion, i.e., that corruption is a bordered, bounded characteristic of individual states. For all their benefits, the spread of large- $N$ quantitative works based on correlations of observational data and country-by-country corruption ratings, and more recent experimental work looking at single country cases studies, mean that this bias is probably becoming worse rather than better. The solution requires a shift in the unit of analysis, to transnational networks, rather than just states, but is compatible with a wide range of methodologies. These can range from more deductive conceptual work like the transaction costs and Global Wealth Chains work referenced earlier, to anthropological participant-observation, to quantitative studies based on observational or experimental data. Thus in Capital Without Borders, Brooke Harrington has illuminated the transnational wealth management industry that safeguards and nurtures the assets of a globalized elite by qualifying to join their professional

82 Andreas and Nadelmann 2006; Andreas 2011, 2015. 
association and multi-site fieldwork at their conferences. ${ }^{83}$ Zucman conducts a quantitative analysis of the flows of funds routed through Luxembourg, Switzerland, and the Cayman Islands. ${ }^{84}$ Findley et al. impersonated a range of high- and low-risk clients in a global field experiment based on soliciting offers for anonymous shell companies from thousands of providers in 180 jurisdictions. ${ }^{85}$ Despite their profound differences, each of these ethnographic, quantitative, and experimental works concentrates on the mingling flows of clean and dirty money moving within professionally-mediated transnational networks. As hard as it might be for scholars to accept, it is notable that through their stings and data-dumps, investigative journalists and NGOs have done more to push our understanding of corruption in a transnational direction that the bulk of academic work on the subject.

That corruption inhibits economic development in poorer countries is almost an article of faith, yet the mechanisms behind this relationship are less well understood. This uncertainty is particularly apparent when it comes to the effect of grand corruption in channeling capital away from productive investment at home to conspicuous consumption in a few major financial centers and "world cities." Tackling this kind of corruption poses new political challenges for the governments of rich countries, in that they must take on politically powerful professional industries, such as lawyers and realtors, who are so adept at easing the flows of both licit and illicit funds.

More broadly, while the political economy of globalization has conventionally focused on the state and corporations, complemented by a more recent strand looking at activists across borders, we suggest that there has been a parallel globalization of the individual. Just as states

\footnotetext{
83 Harrington 2016.

84 Zucman 2015.

85 Findley et al. 2014.
} 
aim to attract companies through tax breaks, they now seek to attract mobile individuals through investor visas. Wealthy individuals and families can avail themselves of the services of a class of professional intermediaries to change things like residence or citizenship from what used to be an accident of birth into a menu of choices. Though there is no reason to suppose the intention is to facilitate the cross-border transfer of illicit wealth, this has often been the end result. 


\section{Bibliography}

Abbott, Kenneth and Duncan Snidal. 2002. Values and Interests: International Legalization in the Fight against Corruption. Journal of Legal Studies 31 (1): 141-178.

Andersson, Staffan and Paul Heywood. 2009. The Politics of Perception: Use and Abuse of Transparency International's Approach to Measuring Corruption. Political Studies 57 (4): 746-767.

Andreas, Peter and Ethan Nadelmann. 2006. Policing the Globe: Criminalization and Crime Control in International Relations. Oxford: Oxford University Press.

Andreas, Peter. 2011. Illicit Globalization: Myths, Misconceptions, and Historical Lessons. Political Science Quarterly 126 (3): 403-425.

Andreas, Peter. 2015. International Politics and the Illicit Global Economy. Perspectives on Politics 13 (3): 782-788.

Author interviews:

Mossack Fonseca, Panama City, Panama, April 2, 2008;

realty broker, Brisbane, Australia, July 17, 2014;

U.S. Treasury Department, Washington D.C., February 12, 2015;

Swiss Financial Intelligence Unit, Geneva, Switzerland, October 13, 2015;

international auditing firm, New York City, May 4, 2015;

National Crime Authority, London, UK, December 14, 2015;

Cayman international bank, Washington D.C., December 9, 2014;

U.S. Department of Justice, Washington D.C., December 9, 2014;

international bank, New York City, November 21, 2014;

international bank, Nassau, the Bahamas, May 13, 2014;

international bank, Hong Kong, October 18, 2011;

OECD, Paris, France, April 19, 2016;

private lawyer, London, UK, December 9, 2015;

citizenship law firm, Basseterre, St Kitts, January 22, 2004 and April 17, 2013;

citizenship law firm, London, UK, December 4, 2015;

citizenship law firms, Geneva, Switzerland, June 16, 2015;

International Centre for Asset Recovery, Basel, Switzerland, October 14, 2015;

Transparency International UK, London, UK, December 10, 2015;

Global Witness, New York City, September 24, 2014;

Open Society Foundations, New York City, February 13, 2015;

private lawyer, Washington D.C., February 10, 2015;

shell company provider, London, UK, April 27, 2016 and December 3, 2015;

shell company provider, Geneva, Switzerland, June 16, 2015 and June 20, 2013;

shell company provider New York City, October 30, 2014;

shell company provider, Nassua, the Bahamas, May 13, 2014; 
shell company provider, Barcelona, Spain, September 25, 2013;

shell company provider, Vaduz, Liechtenstein, June 26, 2013;

shell company provider, Charlestown, Nevis, April 17, 2013;

shell company provider, Port Louis, Mauritius, February 15, 2013;

shell company provider, Victoria, the Seychelles, February 11, 2013;

shell company provider, Avarua, Cook Islands, December 4, 2009;

shell company provider, Singapore, October 20, 2009;

shell company provider, Apia, Samoa, June 29, 2009;

shell company provider, Willemstad, Netherlands Antilles, February 23, 2009.

Baker, Raymond W. 2005. Capitalism's Achilles Heel: Dirty Money and How to Renew the Free-Market System. Hoboken, NJ: Wiley.

Bertrand, Marianne, Simeon Djankov, Rema Hana, and Sendhil Mullainathan. 2007. Obtaining a Driving License in India: An Experimental Approach to Studying Corruption. Quarterly Journal of Economics 122 (4): 1639-1676.

Borlini, Leonardo S. and Guilio Nessi. 2014. International Asset Recovery: Origins, Evolution and Current Challenges. Bocconi University Legal Studies Research Paper Series,

Bukovansky, Mlada. 2006. The Hollowness of Anti-corruption Discourse. Review of International Political Economy 13 (2): 181-209.

Bukovansky, Mlada. 2015. Corruption Rankings: Constructing and Contesting the Global Anti-Corruption Agenda. In Alexander Cooley and Jack Snyder (Eds) Ranking the World: Grading States as a Tool of Global Governance. Cambridge: Cambridge University Press.

Chayes, Sarah. 2015. Thieves of State: Why Corruption Threatens Global Security. New York: W.W. Norton.

Christie's International Real Estate. 2014. Luxury Defined: An Insight into the Luxury Residential Property Market.

Chong, Alberto, L. Ana, Dean Karlan and Leonard Wantchekon. 2015. Does Corruption Information Inspire the Fight or Quash the Hope? A Field Experiment in Mexico on Voter Turnout, Choice, and Party Identification.” Journal of Politics 77 (1): 55-71.

Cooley, Alexander and Jack Snyder (Eds). 2015. Ranking the World: Grading States as a Tool of Global Governance. Cambridge: Cambridge University Press.

Drezner, Daniel W. 2008. All Politics is Global: Explaining International Regulatory Regimes. Princeton: Princeton University Press.

Eigen, Peter. 1996. Combatting Corruption Around the World. Journal of Democracy 7 (1): 158-168. 
Financial Services Authority. 2011. Banks' Management of High Money-Laundering Risk Situations. London.

Findley, Michael G., Daniel L. Nielson, and J.C. Sharman. 2014. Global Shell Games: Experiments in Transnational Relations, Crime and Terrorism. Cambridge: Cambridge University Press.

Fontana, Alessanda. 2011. Making Development Assistance Work at Home. U4 Anti-Corruption Resource Centre Practice Insight. Bergen.

Gereffi, Gary, John Humphrey, and Timothy Sturgeon. 2005. The Governance of Global Value Chains. Review of International Political Economy 12 (1): 78-104.

Global Witness. 2009. Undue Diligence: How Banks do Business with Corrupt Regimes. London.

Global Witness. 2016. "Lowering the Bar: How American Lawyers Told Us to Funnel Suspect Funds into the United States." Washington D.C.

Gottlieb, Jessica. 2016. Greater Expectations: A Field Experiment to Improve Accountability in Mali. American Journal of Political Science 60 (1): 143-157.

Gutterman, Ellen. 2014. The Legitimacy of Transnational NGOs: Lessons from the Experience of Transparency International in Germany and France. Review of International Studies 40 (2): 391-418.

Harrington, Brooke. 2016. Capital Without Borders: Wealth Managers and the One Percent. Cambridge Mass.: Harvard University Press.

Hirschman, Albert O. 1970. Exit, Voice and Loyalty: Responses to Decline in Firms, Organizations and States. Cambridge Mass.: Harvard University Press.

Jakobi, Anja P. 2013. Common Goods and Evils? The Formation of Global Crime Governance. Oxford: Oxford University Press.

Johannesen, Niels and Gabriel Zucman. 2014. The End of Bank Secrecy? An Evaluation of the G20 Tax Haven Crackdown. American Economic Journal: Economic Policy 6 (1): 65-91.

Johnston, Michael. 2005. Syndromes of Corruption: Wealth, Power and Democracy. Cambridge: Cambridge University Press.

Kim, Hun Joon and J.C. Sharman. 2014. Accounts and Accountability: Corruption, Human Rights and Individual Accountability Norms. International Organization 68 (May 2014): 417-448. 
Klitgaard, Robert. 1988. Controlling Corruption. Berkeley: University of California Press.

Lambsdorff, Johann Graf. 2007. The Institutional Economics of Corruption and Reform, Cambridge: Cambridge University Press.

Lambsdorff, Johann Graf. 2013. Corrupt Intermediaries in International Business Transactions: Between Make, Buy and Reform. European Journal of Law and Economics 35 (3): 349-366.

Levi, Michael and Peter Reuter. 2006. Money Laundering. Crime and Justice: A Review of Research edited by M. Tonry 34: 289-374.

Merry, Sally Engle, Kevin E. Davis and Benedict Kingsbury (Eds). 2015. Quiet Power and Indicators: Measuring Governance, Corruption and the Rule of Law. Cambridge: Cambridge University Press.

National Association of Realtors. 2014. Annual Report. Washington D.C.

Obermayer, Bastian and Frederik Obermaier. 2016. The Panama Papers: Breaking the Story of how the Rich and Powerful Hide Their Money. New York: Oneworld Publications.

OECD. 2013.Measuring OECD Responses to Illicit Financial Flows. Paris

OECD. 2014. OECD Foreign Bribery Report: An Analysis of the Crime of Bribery of Foreign Officials. Paris.

Olken, Benjamin. 2007. Monitoring Corruption: Evidence from a Field Experiment in Indonesia. Journal of Political Economy 115 (2): 200-249.

Pieth, Mark (Ed.). 2008. Recovering Stolen Assets. Bern: Peter Lang.

Reuter, Peter (Ed). 2012. Draining Development? Controlling Flows of Illicit Funds from Developing Countries. Washington DC: World Bank.

Reuter, Peter and Edwin Truman. 2004. Chasing Dirty Money: The Fight against Money Laundering. Washington D.C. Institute for International Economics.

Rodrik, Dani. 2008. The New Development Economics: We Shall Experiment, but How Shall we Learn? Harvard Kennedy School Research Working Paper RWP08-055.

Rose-Ackerman, Susan. 1999. Corruption and Government: Causes, Consequences and Reform. Cambridge: Cambridge University Press.

Rose-Ackerman, Susan. 2010. The Law and Economics of Bribery and Extortion. Annual Review of Law and Social Science 6 (1): 217-238. 
Rosen, Kenneth, Arthur Margon, Randall Sakamoto, and John Taylor 2016. Breaking Ground: Chinese Investment in U.S. Real Estate. New York: Asia Society.

Rothstein, Bo. 2011. Anti-Corruption: The Indirect "Big Bang” Approach. Review of International Political Economy 18 (2): 228-250.

Sanchez, Gabriella E. 2014. Human Smuggling and Border Crossings. New York: Routledge.

Seabrooke, Leonard and Duncan Wigan. 2014. Global Wealth Chains in the International Political Economy. Review of International Political Economy. 21 (1): 257-263.

Shachar, Aylet and Rainer Bauböck. 2014. Should Citizenship be for Sale? European University Institute Working Paper.

Shelley, Louise. 2014. Dirty Entanglements: Corruption, Crime, and Terrorism. New York: Cambridge University Press.

Shleifer, Andrei and Robert W Vishny. 2002. The Grabbing Hand: Government Pathologies and their Cures. Cambridge Mass.: Harvard University Press.

StAR. 2007. Stolen Asset Recovery (StAR) Initiative: Challenges, Opportunities, and Action Plan. Washington: World Bank/United Nations Office on Drugs and Crime.

StAR. 2009. Politically Exposed Persons: A Policy Paper on Strengthening Preventive Measures. Washington: World Bank/United Nations Office on Drugs and Crime

StAR. 2011. The Puppet Masters: How the Corrupt use Legal Structures to Hide Stolen Assets and What to Do About It. Washington: World Bank/United Nations Office on Drugs and Crime

StAR. 2014a. Left Out of the Bargain: Settlements in Foreign Bribery Cases and Implications for Asset Recovery. Washington: World Bank/United Nations Office on Drugs and Crime.

StAR. 2014b. Few and Far: The Hard Facts on Stolen Asset Recovery. Washington: World Bank/United Nations Office on Drugs and Crime.

Transparency International United Kingdom. 2015a. Corruption on your Doorstep: How Corrupt Capital is Used to Buy Property in the UK. London.

Transparency International United Kingdom. 2015b. Gold Rush: Investment Visas and Corrupt Capital Flows into the UK. London.

Treisman, Daniel. 2007. What Have We Learned about the Causes of Corruption from Ten Years of Cross-National Research? Annual Review of Political Science. 10 (1): 211-244. 
U.S. Senate. 2010. Keeping Foreign Corruption out of the United States: Four Case Histories. Permanent Subcommittee on Investigations. Washington D.C.

United Nations Office on Drugs and Crime. 2011. Estimating Illicit Financial Flows Resulting from Drug Trafficking and Other Transnational Organized Crimes. Vienna.

Van Fossen, Antony. 2012. Tax Havens and Sovereignty in the Pacific Islands. St Lucia: University of Queensland Press.

Vogl, Frank. 2012. Waging War on Corruption: Inside the Movement Fighting the Abuse of Power. Lanham MD: Rowman and Littlefield.

Wang, Hongying and James N. Rosenau. 2001. Transparency International and Corruption as an Issue of Global Governance. Global Governance 7 (1): 25-49.

Wedel, Janine R. 2012. Rethinking Corruption in an Age of Ambiguity. Annual Review of Law and Social Science 8 (1): 453-498.

Williamson, Oliver E. 1975. Markets and Hierarchies: Analysis and Anti-Trust Implications. New York: Free Press.

Williamson, Oliver E. 1985. The Economic Institutions of Capitalism. New York: Free Press.

Zucman, Gabriel. 2015. The Hidden Wealth of Nations: the Scourge of Tax Havens. Chicago: University of Chicago Press. 


\section{Table 1}

Summary of Rules Governing Obligations of Real Estate Brokers to Identify Purchasing Individual in All-Cash Transactions (Top 10 Global Luxury Markets)

\begin{tabular}{|c|c|c|c|}
\hline Country & $\begin{array}{l}\text { Market(s) and (Rank- in } \\
\text { Christie's Luxury Real } \\
\underline{\text { Estate Index) }}\end{array}$ & $\begin{array}{l}\frac{\text { Real Estate Broker }}{\text { Transparency and }} \\
\text { Reporting } \\
\underline{\text { Obligations }}\end{array}$ & $\begin{array}{l}\text { Notes on Enforcement of } \\
\text { AML Guidelines by Real } \\
\text { Estate Professionals } \\
\text { Rules (FATF Mutual } \\
\text { Evaluation report date) }\end{array}$ \\
\hline$\underline{\text { United }}$ & London (1) & $\begin{array}{l}\text { Brokers must ascertain } \\
\underline{\text { identity and financial }} \\
\underline{\text { means of sellers, not }} \\
\underline{\text { buyers }}\end{array}$ & $\begin{array}{l}\text { "Currently no AML/CFT } \\
\text { supervision for real estate } \\
\text { agents or TCSPs that are not } \\
\text { legal or accountancy } \\
\text { professionals.." }(2009,15)\end{array}$ \\
\hline $\begin{array}{l}\text { United } \\
\text { States } \\
\end{array}$ & 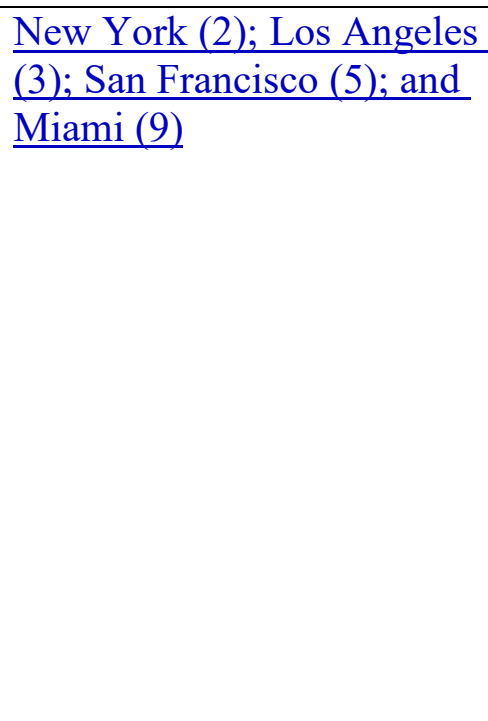 & $\begin{array}{l}\text { None; Waiver granted to } \\
\text { AML requirements of } 2001 \\
\text { Patriot Act } \\
\text { 2016 FinCEN rules on } \\
\text { all-cash transactions target } \\
\text { Title Insurance Companies } \\
\text { in six major markets. }\end{array}$ & $\begin{array}{l}\text { "Neither the real estate agents } \\
\text { nor the RMLO sector appeared } \\
\text { to understand what the ML } \\
\text { risks in relation to high-end real } \\
\text { estate are or what the } \\
\text { appropriate mitigation measures } \\
\text { would be" (2016, 125) } \\
\text { "Other DNFBPs are subject to } \\
\text { only limited supervision as a } \\
\text { result of their limited } \\
\text { obligations. This is a } \\
\text { fundamental deficiency when } \\
\text { looked at in the context of risk } \\
\text { relating to legal persons and } \\
\text { high-end real estate in } \\
\text { particular." (2016, 234-235) }\end{array}$ \\
\hline
\end{tabular}




\begin{tabular}{|c|c|c|c|}
\hline China & Hong Kong (4) & $\begin{array}{l}\frac{\text { Brokers must ascertain }}{\text { identity of individual }} \\
\text { clients or their } \\
\text { representatives for LLC, } \\
\text { but not beneficial owner }\end{array}$ & $\begin{array}{l}\text { "More progress is nevertheless } \\
\text { required to develop an } \\
\text { appropriate AML/CFT } \\
\text { regulatory framework for } \\
\text { DNFBPs, and ensure, as it is } \\
\text { already the case for lawyers and } \\
\text { real estate agents, that } \\
\text { non-compliant DNFBPs are } \\
\text { sanctioned. This deficiency has } \\
\text { been partially addressed." } \\
(2012,31-32)\end{array}$ \\
\hline France & $\begin{array}{l}\text { Paris (7); and Cote D'Azure } \\
(8)\end{array}$ & $\begin{array}{l}\text { Notaires considered neutral } \\
\text { parties with financial } \\
\text { liability for the transaction; } \\
\text { must ascertain if buyer has } \\
\text { the necessary financial } \\
\text { resources; }\end{array}$ & $\begin{array}{l}\text { "At the time of the on-site visit, } \\
\text { the internal AML/CFT control } \\
\text { procedures and measures } \\
\text { applicable to non-financial } \\
\text { professions (Recommendation } \\
\text { 15) were either totally lacking or } \\
\text { very mediocre. This was the } \\
\text { case for casinos, real estate } \\
\text { agents, company domiciliation } \\
\text { agents and jewellers." (2011, } \\
\text { 15) }\end{array}$ \\
\hline Australia & Sydney (6) & & $\begin{array}{l}\text { "Most designated non-financial } \\
\text { business and profession sectors } \\
\text { are not subject to AML/CTF } \\
\text { requirements, and did not } \\
\text { demonstrate an adequate } \\
\text { understanding of their ML/TF } \\
\text { risks or have measures to } \\
\text { mitigate them effectively. This } \\
\begin{array}{l}\text { includes real estate agents and } \\
\text { lawyers, both of which have }\end{array} \\
\begin{array}{l}\text { been identified to be of high } \\
\text { ML risk in Australia's National }\end{array} \\
\text { Threat Assessment." (2015,6) } \\
\text { "Australia is seen as an } \\
\text { attractive destination } \\
\text { for foreign proceeds, } \\
\text { particularly corruption-related } \\
\text { proceeds flowing into real } \\
\text { estate, from the Asia-Pacific } \\
\text { region. } \\
\text { (2016, 7) }\end{array}$ \\
\hline
\end{tabular}




\begin{tabular}{|c|c|c|c|}
\hline$\underline{\text { Canada }}$ & $\underline{\text { Toronto }(10)}$ & $\begin{array}{l}\frac{\text { Brokers legally required to }}{\text { report real estate agents are }} \\
\text { obliged to report } \\
\text { suspicious activity and all } \\
\text { cash transactions totaling } \\
\text { more than } \$ 10,000 \text {. } \\
\text { Reporting in practice is } \\
\begin{array}{l}\text { irregular; from } 2010 \text { to } \\
\text { we15 no real estate brokers }\end{array} \\
\text { violations; }\end{array}$ & $\begin{array}{l}\text { "Most DNFBPs are not } \\
\text { sufficiently aware of their } \\
\text { AML/CFT obligations. This is } \\
\text { in particular the case of real } \\
\text { estate agents." }(2016,7) \\
\text { "While FIs generally appear } \\
\text { adequately aware of their } \\
\text { ML/TF risks, the same does not } \\
\text { apply in some DNFBP sectors, } \\
\text { in particular the real estate } \\
\text { sector." }(2016,7,19) \text {. }\end{array}$ \\
\hline
\end{tabular}

Sources: Christie's 2014, p. 24; FATF Mutual Monitoring Reports for Specific Countries 
Table 2

Summary of Post-Financial Crisis (2008-) OECD Country Investment Residency Regimes

Source: Modified from OECD; http://www.oecd.org/migration/46451375.xls

\begin{tabular}{|c|c|c|c|}
\hline Country & Title of Program & $\begin{array}{c}\text { Financial } \\
\text { Requirements/Employment } \\
\text { Creation Metrics }\end{array}$ & $\begin{array}{l}\text { Date Enacted } \\
\text { or Amended } \\
\text { (Date of } \\
\text { Original } \\
\text { Legislation) }\end{array}$ \\
\hline Australia & $\begin{array}{l}\text { "Investor" "Significant } \\
\text { Investor" }\end{array}$ & $\begin{array}{c}\text { Significant Investor: A } \$ 5 \\
\text { million in approved investments } \\
\text { Premium Investor: A } \$ 15 \text { million } \\
\text { in approved investments }\end{array}$ & 2012 \\
\hline Austria & NONE NEW post-2008 & & \\
\hline Belgium & NONE NEW post-2008 & & \\
\hline Canada & Start-up Visa Program & & 2014 \\
\hline Chile & & $\begin{array}{l}\text { No minimum, requirement of } \\
\text { "recurring income" }\end{array}$ & 2012 \\
\hline Czech Republic & NONE NEW post-2008 & & \\
\hline Denmark & NONE NEW post-2008 & & \\
\hline Estonia & E-residency program & $\begin{array}{c}\text { Establish LLC, contribution of } \\
2500 \text { EUR }\end{array}$ & 2014 \\
\hline Finland & NONE NEW post-2008 & & \\
\hline France & $\begin{array}{c}\text { "Exceptional Economic } \\
\text { Contribution" residency permit }\end{array}$ & 50 jobs & 2009 \\
\hline Germany & NONE NEW post-2008 & & \\
\hline Greece & $\begin{array}{l}\text { Residence permit for the } \\
\text { purpose of exercising an } \\
\text { independent economic activity }\end{array}$ & 60,000 EUR & 2014 \\
\hline Hungary & $\begin{array}{l}\text { Hungarian Investment } \\
\text { Immigration Program }\end{array}$ & $\begin{array}{l}250,000 \text { EUR bond purchase w/ } \\
\text { minimum 5-yr maturity }\end{array}$ & 2013 \\
\hline Iceland & $\begin{array}{l}\text { NONE- ad hoc application in } \\
2011 \text { for citizenship from } 10 \\
\text { North American investors } \\
\text { requesting citizenship }\end{array}$ & & \\
\hline Ireland & Business permission & 300,000 EUR & 2012 \\
\hline Israel & $\begin{array}{l}\text { Granting of E-2 Equivalent } \\
\text { Visas to American Investors }\end{array}$ & $\begin{array}{c}\text { For US investors and essential } \\
\text { employees }\end{array}$ & 2014 \\
\hline Italy & NONE NEW post-2008 & & \\
\hline Japan & NONE NEW post-2008 & & \\
\hline Korea & $\begin{array}{l}\text { Business Investment visa D8 } \\
\text { for entrepreneurs/managers }\end{array}$ & 50,000 USD & 2010 \\
\hline Luxembourg & NONE NEW post-2008 & & \\
\hline Mexico & NONE NEW post-2008 & & \\
\hline Netherlands & $\begin{array}{l}\text { Residence permit for labor as } \\
\text { self-employed }\end{array}$ & $\begin{array}{c}\text { 10-35 persons, depending on } \\
\text { activity }\end{array}$ & $2013(2008)$ \\
\hline
\end{tabular}




\begin{tabular}{|c|c|c|c|}
\hline New Zealand & $\begin{array}{c}\text { Long Term Business Visa/ } \\
\text { Entrepreneur and Entrepreneur } \\
\text { plus visas }\end{array}$ & $\begin{array}{c}\text { Buy or maintain existing } \\
\text { business; demonstrate sufficient } \\
\text { funds for } 3 \text { years proposed } \\
\text { activity }\end{array}$ & $\begin{array}{l}2009 \text { (revised } \\
\text { from 2002, } \\
1999 \text { ) }\end{array}$ \\
\hline Norway & NONE NEW post-2008 & & \\
\hline Poland & NONE NEW post-2008 & & \\
\hline Portugal & Golden Visa Investor Program & $\begin{array}{c}\text { Property ownership of } € 500,000 \\
\text { plus language competency }\end{array}$ & \\
\hline Slovak Republic & NONE NEW post-2008 & & \\
\hline Slovenia & NONE NEW post-2008 & & \\
\hline Spain & $\begin{array}{l}\text { Residence permit for } \\
\text { self-employment }\end{array}$ & $\begin{array}{c}\text { Demonstrate } 1 \text { year of } \\
\text { maintenance funds and create } \\
\text { employment }\end{array}$ & 2013 \\
\hline \multicolumn{4}{|l|}{ Sweden } \\
\hline Switzerland & $\begin{array}{l}\text { Residence permit for the } \\
\text { practice of an independent } \\
\text { economic activity }\end{array}$ & $\begin{array}{l}\text { Proposed activity serves the } \\
\text { economic interest of } \\
\text { Switzerland/ positive } \\
\text { mid/long-term effects on the } \\
\text { Swiss labor market }\end{array}$ & 2008 \\
\hline Turkey & $\begin{array}{l}\text { Residence permit, E-visa } \\
\text { program }\end{array}$ & Property ownership & 2014 \\
\hline United Kingdom & $\begin{array}{l}\text { Tier } 1 \text { Entrepreneur } \\
\text { subcategory }\end{array}$ & $2,000,000 \mathrm{GPB}$ & 2009 \\
\hline United States & NONE NEW post-2008 & & \\
\hline
\end{tabular}

